\title{
Rozwój szkolnictwa dla mniejszości tubylczych na Alasce
}

\begin{abstract}
Development of Education for Indigenous Minorities in Alaska
The article deals with the issue of the relation between education and processes of the development of ethnic identity of indigenous minorities in Alaska. Particular emphasis was placed on reconstructing the educational practices and policy that is being implemented for indigenous minorities within the school system (especially assimilation, discrimination and revitalisation of ethnic identity). An attempt was made at examining the relationship between schooling, socialisation, language policy, and the development of aboriginal minorities in Alaska.
\end{abstract}

Keywords: education, indigenous minorities, Alaska, ethnic identity, assimilation, discrimination, revitalisation, language policy

\section{Wprowadzenie}

Alaska to czterdziesty dziewiąty stan USA, którego powierzchnia jest pięciokrotnie większa od terytorium Polski. Jego nazwa pochodzi z języka Aleutów - „Alayeksha”, co oznacza „Wielka Ziemia”.1. Aktualnie na Alasce funkcjonuje kilka głównych ośrodków miejskich - Anchorage, Fairbanks, Juneau, Sitka, Kenai, a także około dwudziestu mniejszych miasteczek i stu osiemdziesięciu osad. Alaska jest największym pod względem powierzchni stanem USA, a przy tym obszarem najsłabiej zaludnionym. Terytoria stanu Alaska od tysiącleci były miejscem zamieszkiwania różnych społeczności tubylczych.

\footnotetext{
${ }^{1}$ A. Jahn, Alaska, Warszawa 1966, s. 9.
} 
Współcześnie jednak, wskutek masowych procesów migracji, ludność tubylcza stanowi zaledwie czwartą część populacji tego stanu².

$\mathrm{Na}$ terytorium Alaski zamieszkuje bardzo różnorodna pod względem etnicznym i językowym populacja tubylcza ${ }^{3}$. Stan ten zamieszkuje ponadto wiele innych grup etnicznych, z czego znaczną część stanowią imigranci. Aktualnie, przynależność tubylczą na Alasce deklaruje około 138000 osób, co stanowi około 24,2\% całej populacji stanu 4 . Największe grupy tubylcze stanowią Eskimosi Jupik (33 889 osób) oraz Inupiak (33 360 osób), a także Indianie Tlingit-Haida (26 080 osób), Indianie Athabaski - zamieszkujący na Alasce (22 484 osoby) oraz Aleuci (19 282 osoby) $)^{5}$.

Obszar kulturowy i językowy jest bardzo urozmaicony. Alaskę zamieszkują reprezentanci odmiennych grup etnicznych, różniących się pochodzeniem, historią, kulturą oraz wierzeniami ${ }^{6}$, a współcześnie także stopniem akulturacji ${ }^{7}$. Trzeba zauważyć, że nawet w ramach tych grup wyróżnia się wiele podgrup, które wywodziły się z dawnych plemion, społeczności, czy grup regionalnych. Na przykład w ramach jednej tylko grupy etnicznej - Eskimosów Iñupiaq, E. S. Burch wyróżnił jedenaście podgrup, zamieszkujących w połowie XIX w. północno-zachodnie obszary Alaski ${ }^{8}$.

Także w sferze lingwistycznej dostrzegalne są wyraźne różnice - zarówno w zakresie funkcjonowania odrębnych języków, jak i w sferze występowania poszczególnych dialektów. Tubylcza populacja często dzielona jest na trzy główne grupy - w zależności od używanego języka, kultury oraz miejsca zamieszkania (Eskimosów, Indian i Aleutów). W ramach tych grup funkcjonują cztery główne rodziny językowe (eskimosko-aleucka, atapaskańska-eyak-tlingit, tsimshian i haida), które tworzą dwadzieścia odrębnych języków9.

Ludy zamieszkujące po obu stronach Cieśniny Beringa były ze sobą w nieustannym kontakcie. Na przykład plemiona inuickie (eskimoskie) zamieszkujące obszary Alaski były odwiedzane przez syberyjskich Czukczów. Celem była przede wszystkim wymiana towarowa. Czukcze oferowali Inuitom stal, tytoń, a także skóry tamtejszych reniferów, wymieniając swoje produkty na produkty z ssaków morskich, nefryty, a także futra zwierząt. Naturalna granica, jaką była Cieśnina Beringa, nie stanowiła bariery, lecz szlak umożliwiający wzajemne kontakty ${ }^{10}$.

2 T. Norris, P. L. Vines, E. M. Hoeffel, The American Indian and Alaska Native Population: 2010, s. 7, 2010 Census Briefs, United States Department of Commerce Economics and Statistics Administration, U.S. Census Bureau, adres Internetowy: http://www.census.gov/prod/cen2010/briefs/c2010br-10.pdf

3 Por. M. E. Krauss, Alaska Native Languages: Past, Present, Future, Fairbanks 1980, s. 15.

${ }^{4}$ T. Norris, P. L. Vines, E. M. Hoeffel, op. cit., s. 7.

${ }^{5}$ Ibidem, s. 18-19.

${ }^{6}$ A. Jahn, op. cit., s. 197-207.

${ }^{7}$ N. H. H. Graburn, B. S. Strong, Circumpolar Peoples: An Anthropological Perspective, "Pacific Palisades" 1973, s. 183.

${ }^{8}$ E. S. Burch, The Iñupiaq Eskimo Nations of Northwest Alaska, Fairbanks 1998, s. 8-12.

9 C. Barnhard, A History of Schooling for Alaska Native People, ,Journal of American Indian Education” 2001, t. 40, nr 1, s. 2.

${ }^{10}$ S. D. M. Rowley, Inua: Spirit World of the Bering Sea Eskimo, Washington 1988, s. 7-8. 


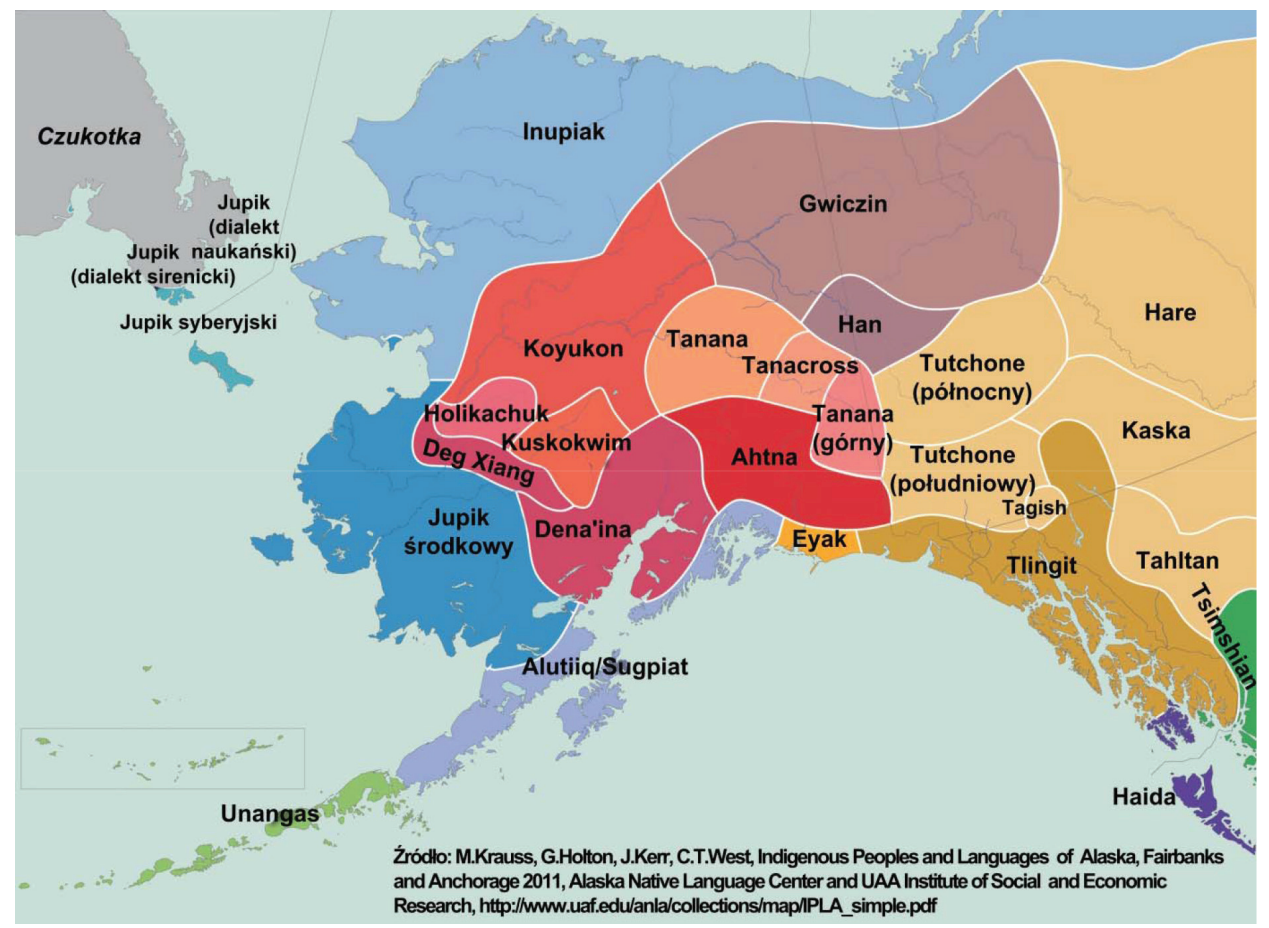

Mapa 1. Umiejscowienie tubylczych ludów i języków na Alasce

Wierzenia odmiennych grup etnicznych zamieszkujących na Alasce stanowią odrębną dziedzinę badań. Ich podobieństwo i różnorodność stanowią pole dla wielu analiz i debat naukowych. Różnorodność tych wierzeń, ich złożoność stanowi dowód na niezwykle rozwinięty świat metafizyczny i kulturowy grup etnicznych zamieszkujących północne obszary $^{11}$.

Dotyczy to również społeczności eskimoskich zamieszkujących w obszarze Morza Beringa, którzy rozwinęli złożony system wierzeń, w których istotną rolę odgrywał szamanizm $^{12}$. Także gospodarka Inuitów (podobnie jak innych społeczności tubylczych Alaski) była ściśle powiązana z cyklem pór roku. Wiosna rozpoczynała tradycyjny cykl polowań i gromadzenia pokarmu na długie zimowe miesiące. Tradycyjnym elementem wyposażenia myśliwego był kajak [qayaq]. Ważnym środkiem transportu były również większe łodzie, tak zwane umiaki. Łodzie takie mogły pomieścić około 10-15 osób wraz z dobytkiem i psami. Używane były do przemieszczania większych grup, zmiany miejsca obozowiska, wizyt gościnnych itp. Ułatwiały one znacznie transport, przemieszczanie się

11 Por. T. Walendziak, Eskimosi, seria Mitologie Świata, Warszawa 2008, s. 15-20, oraz L. Olchowik-Adamowska, E. Biernacka, Indianie Ameryki Pótnocnej, seria Mitologie Świata, Warszawa 2007, s. 9-10.

12 S. D. M. Rowley, op. cit., s. 63-69. 
bowiem na większe odległości drogą lądową powiązane było z juczeniem psów i przenoszeniem bagażu na plecach. W pewnych regionach (np. Półwyspu Seward) umiaki używane były także do polowań na białuchy (wale białe) i morsy ${ }^{13}$.

Eskimosi żyjący na Alasce zamieszkiwali przede wszystkim w chatach z drewna, kamienia i torfu. W niektórych miejscach, w obozowiskach zimowych mężczyźni zamieszkiwali osobno w tzw. qasgiq. Były to większe drewniane domostwa, miejsca spotkań towarzyskich i życia społeczności. Część z nich przykrywana była warstwą ziemi torfowej w celu izolacji przez zimnem. W wyjątkowych przypadkach, mogły w nich spać również kobiety i dzieci. Z kolei w okresie letnim zamieszkiwano w domostwach innego typu (mogły to być bardziej przestronne i jasne chaty z drewna lub namioty z futer karibu, lub skór foczych) ${ }^{14}$.

Specyficzne zwyczaje i wierzenia Inuitów dotyczyły każdej sfery życia. Dzieci przychodziły na świat w osobnym miejscu położonym niedaleko od miejsca zamieszkania rodziny. W okresie zimowym było to zwykle śnieżne igloo, natomiast w okresie letnim mały namiot ze skór. Według wierzeń Eskimosów, nowo narodzone dziecko miało ciało (timi), duszę (iñuusriq), życie/oddech (anigniq) oraz osobowość (ilitqusriq), nie miało jednak imienia (atiq). Jak zauważa przy tym E. S. Burch, bez imienia nie było ono $w$ petni człowiekiem. Nadanie imienia było jednym z pierwszych istotnych zadań społeczności wobec swego nowego członka. Imię nadawali zwykle członkowie rodziny (matka, ojciec, dziadkowie lub bliscy krewni) i było to zwykle imię po zmarłym krewnym. Wszystkie imiona były neutralne pod względem płciowym. Praktyka nadawania imion prowadziła do tendencji nadawania specyficznych imion $w$ zależności od poszczególnych społeczności; posiadajaca tę wiedze jednostka z zewnatrz mogła odgadnać, skąd pochodzi dana osoba jedynie po jej imieniu. Iñupiat z obszarów północno-zachodniej Alaski nie obliczali wieku jednostki w latach. Charakterystyka dotyczyła dojrzałości jednostki do podejmowania określonych ról w plemiennej społeczności ${ }^{15}$.

Socjalizacja w społecznościach eskimoskich Alaski wprzęgnięta była w życie codzienne. Stopniowo, role dzieci były różnicowane w zależności od płci. Dziewczynki podejmowały więcej czynności związanych z przygotowaniem jedzenia, preparowaniem i szyciem skór, czy zastawianiem sideł na pardwy tundrowe i zające. Z kolei chłopcy, podejmowali zadania związane $\mathrm{z}$ wyprawami łowieckimi i nauką polowania ${ }^{16}$. Równocześnie trzeba zauważyć, że podział ról nie był jednoznacznie określony (np. zdarzało się, że kobiety uczestniczyły w wyprawach łowieckich). Ponadto, kobiety (choć rzadziej niż mężczyźni) podejmowały role szamanów. Jednak, jak zauważa E. S. Burch, wiele najbardziej potężnych szamanów było kobietami ${ }^{17}$.

\footnotetext{
13 Ibidem, s. 19.

${ }^{14}$ Ibidem, s. 55-56.

15 E. S. Burch, Social Life in Northwest Alaska. The Structure of Iñupiaq Eskimo Nations, Fairbanks 2006, s. $58-59$.

16 Ibidem, s. 59.

17 Ibidem, s. 65.
} 
Współcześnie, procesy przyspieszonej modernizacji spowodowały szybką asymilację społeczności tubylczych w główny nurt kultury amerykańskiej. Powoduje to postępujący zanik tradycyjnych zwyczajów, a także zmiany w systemach wartości, które wytworzyły i którym wierne były tubylcze społeczności przez setki lat. Równocześnie, dostrzegalna jest znaczna dynamika w sferze zaniku tubylczych języków na Alasce.

\section{Polityka edukacyjnej asymilacji na Alasce}

Kolonizacja Alaski rozpoczęła się od wypraw podejmowanych przez Cieśninę Beringa. W XVI w. rosyjscy handlarze futrami zapuszczali się głównie do wybrzeży Syberii, z rzadka tylko wchodząc kontakty z Eskimosami zamieszkującymi na Alasce. Vitus Bering, którego ekspedycja zorganizowana została na polecenie carycy Katarzyny, odkrył Aleutów ${ }^{18}$. Ekspansja rosyjskich odkrywców i handlarzy na Wyspy Aleuckie spowodowały znaczne wyniszczenie rodzimej ludności, wskutek walk oraz przywleczonych chorób $^{19}$. Miary zniszczenia dopełniła grabieżcza eksploatacja zasobów naturalnych (m.in. tępienie zwierzyny dla futer) ${ }^{20}$.

Także początki działalności edukacyjnej na Alasce powiązane są z procesami kolonizacji tych obszarów przez białych osadników. Cechowała ją brutalność kolonizatorów wobec tubylczych społeczności. W 1784 r. rosyjski handlarz futrami Griegorij Szelichow utworzył punkt handlowy w dzisiejszej miejscowości Three Saints Bay na południowo-zachodnim wybrzeżu wyspy Kodiak. Wymordował on znaczną liczbę tubylczych mieszkańców tego obszaru, biorąc pozostałych w niewolę. Równocześnie, tworząc podstawy dla panowania nad wyspą, otworzył szkołę dla dzieci tubylców, w której nauczał «moralności chrześcijańskiej», arytmetyki oraz języka rosyjskiego ${ }^{21}$. Instytucja ta dała początek szkołom misyjnym tworzonym po przybyciu w 1796 r. na tereny Alaski prawosławnych misjonarzy. Chrystianizacja Eskimosów na Alasce rozpoczęła się już w czasach carskich. W 1845 r. założono kolejne misje Kościoła prawosławnego. Współcześnie, wielu Inuitów (Jupik) nadal należy do Rosyjskiego Kościoła Prawosławnego ${ }^{22}$.

Powstawanie nowych szkół misyjnych miało miejsce w obszarach, w których funkcjonowały rosyjskie kompanie handlujące futrami (w szczególności na Wyspach Aleuckich, wyspie Kodiak, a także na terenach półwyspu Alaski i jej części południowowschodniej). Rosyjscy zakonnicy i zakonnice podejmowali wysiłki zmierzające do opanowania języków społeczności tubylczych i na tej podstawie tworzyli system pisma (w tym celu wykorzystywali cyrylicę). Założeniem prawosławnych misjonarzy nie była

${ }^{18}$ S. D. M. Rowley, op. cit., s. 7.

19 A. Jahn, op. cit., s. 225.

${ }^{20}$ N. H. H. Graburn, B. S. Strong, op. cit., s. 133.

${ }^{21}$ Report of the Education task Force, Alaska Natives Commision/Alaska Federation of Natives, 1995, w: Alaska Native Education. Views From Within, red. R. Barnhardt, A. O. Kawagley, Fairbanks 2010, s. 7.

22 Ibidem, s. 8. 
eliminacja języków mniejszości, lecz wykorzystanie ich w celu chrystianizacji i wykorzenienia pierwotnych praktyk religijnych (np. szamanizmu). Ponadto, jak zauważa M. S. T. Williams, często przeciwstawiali się oni złemu traktowaniu tubylczych mieszkańców przez rosyjskich kolonizatorów oraz przedstawicieli kompanii futrzarskich, którzy często praktykowali niewolnictwo i gwałt ${ }^{23}$.

Z kolei obszary wybrzeża wzdłuż Morza Beringa (pomiędzy rzekami Jukon i Kuskokwim) zamieszkane przez w znacznym stopniu rozproszone populacje Inuitów Jupik były skolonizowane znacznie później. W praktyce, dopiero w latach 80 . XIX w. przybycie misjonarzy katolickich i morawskich legło u podstaw zmian w sposobach funkcjonowania mniejszości w tych obszarach. Jedną z przyczyn głębokiego kryzysu demograficznego były choroby przywleczone przez białych ludzi. W 1900 r. epidemia grypy zabiła ponad połowę populacji regionu, i choć niewielkie społeczności na wybrzeżu nie zostały tak mocno dotknięte, to jednak większość zimowych osad uległa zagładzie. Inną przyczyną zmian w sposobach gospodarowania była gorączka złota w Nome. Warto jednak zauważyć, że populacje zamieszkujące osady na wybrzeżu Morza Beringa aż po pierwsze dekady powojenne $\mathrm{w}$ znacznym stopniu opierały się narzucanym przez instytucje kościelne i państwowe sposobom życia i gospodarowania ${ }^{24}$.

Przybycie w latach 80. i 90. XIX w. misjonarzy amerykańskich (głównie prezbiterian, kwakrów, baptystów oraz katolików), zmieniło sposoby podejścia wobec społeczności tubylczych na Alasce. Przedmiotem ataków stały się szczególnie języki tubylcze, a celem misjonarzy stało się wyeliminowanie ich użycia. Równocześnie, postrzegali oni muzykę i taniec oraz szamanizm jako niebezpieczne i diabelskie; powszechne byty rasistowskie, etnocentryczne opisy tubylczych ludów Alaski, w oczywisty sposób uprawomocniające brutalne środki używane przez misjonarzy w procesach chrystianizacji. Jedynym uznanym językiem był angielski. Z kolei, morawscy misjonarze którzy rozpoczęli swoją działalność w obszarze delty Jukon-Kuskokwim w 1885 r., uważali za konieczne używanie języka jupik w procesach ewangelizacji. W konsekwencji, również współcześnie w miejscowościach, w których działały misje morawskie, język jupik ma silny status ${ }^{25}$.

W rezultacie tej polityki, używanie tubylczych języków Alaski było zabronione w szkolnictwie Alaski aż do lat 60 . XX w. Języki tubylcze były postrzegane jako «szkodliwe» dla procesów cywilizowania autochtonicznych populacji. Chrześcijaństwo było uważane za niekompatybilne z żadnym innym językiem poza angielskim, ani z żadna inna kultura poza zachodnioeuropejska/amerykańską ${ }^{26}$. Doprowadzało to do sytuacji, w której reprezentanci tubylczych grup zmuszeni byli do wybierania nie tylko samego języka,

${ }^{23}$ M. S. T. Williams, The Comity Agreement: Missionization of Alaska Native People, w: The Alaska Native Reader. History, Culture. Politics, red. M. S. T. Williams, Durham 2009, s. 154.

${ }^{24}$ A. Fienup-Riordan, The Yupiit of Western Alaska, w: Endangered Peoples of the Arctic. Struggles to Survive and Thrive, red. M. M. R. Freeman, Westport 2000, s. 253.

${ }^{25}$ M. S. T. Williams, op. cit., s. 155-156.

${ }^{26}$ N. Vakhtin, The Russian Arctic between Missionaries and Soviets: The Return of Religion, Double Belief, or Double Identity?, w: Rebuilding Identities. Pathways to Reform in Post-Soviet Siberia, red. E. Kasten, Halle 2005, s. 30-31. 
lecz w rzeczywistości zmiany kodu językowego [code-swiching], w zależności od zewnętrznych oczekiwań kolonizatorów ${ }^{27}$.

Elementem sprzyjającym rozwojowi szkół misyjnych stała się również działalność Kompanii Rosyjsko-Amerykańskiej, która za zgodą cara Rosji zmonopolizowała wydobycie bogactw naturalnych na tym obszarze. Kompania rozpoczęła kształcenie techniczne pierwotnych mieszkańców Alaski oraz jednostek pochodzących ze związków mieszanych. Celem działania powstałych szkół zawodowych było wykorzystanie lokalnej siły roboczej dla potrzeb Kompanii, a także „chrystianizacja” i „cywilizowanie” tubylczych mieszkańców. Od chwili sprzedaży Alaski i jej przejścia pod jurysdykcję amerykańską, szkoły zawodowe prowadzone przez Kompanię Rosyjsko-Amerykańską uległy zamknięciu. Z kolei, szkoły misyjne działały dalej (niektóre z nich aż do 1916 r.), otrzymując wsparcie od rządu rosyjskiego ${ }^{28}$.

Rozwój szkół w kolejnych dekadach po 1867 r. powiązany był z działalnością misyjną (głównie Kościoła protestanckiego i rzymsko-katolickiego) - wspieraną przez instytucje państwowe, których uosobieniem była administracja wojskowa. Ich cele były zorientowane jednoznacznie - podobnie jak w dekadach wcześniejszych - na chrystianizowanie i cywilizowanie tubylczych populacji. Indoktrynacja religijna była w tym kontekście postrzegana jako najskuteczniejszy środek „cywilizowania” tubylców. Terytorium Alaski podzielone zostało na regiony misyjne, w ramach których misjonarze reprezentujący poszczególne wyznania prowadzili swoją działalnośćc ${ }^{29}$. Wierzenia tubylcze zlewały się z nową wiarą (np. idea grzechu zastąpiła dawne tabu), a dawne szamanistyczne rytuały zastąpione zostały nową symboliką chrześcijańską (czary zastąpione zostały przez cudy, pieśni przez modlitwy). Na przykład, misjonarze zabraniali polowania w niedzielę, co powiązane zostało przez Eskimosów z North Slope z dawnymi tabu ${ }^{30}$.

Szkoły religijne na Alasce działały na podstawie ustawy uchwalonej jeszcze w $1819 \mathrm{r}$. w sprawach amerykańskich Indian (Civilization Fund Act). Ustawa ta dawała rządowi amerykańskiemu praktycznie niegraniczone możliwości w zakresie decyzji dotyczących nieomal wszystkich aspektów życia tubylczych populacji (włączając w to edukację, religię, medycynę, prawo, możliwości polowania i połowów ryb, a także dysponowanie ziemię i jej zasobami). Przejście Alaski pod jurysdykcję amerykańską spowodowało rozciągnięcie oddziaływania ustawy na tubylcze populacje zamieszkujące ten $\operatorname{stan}^{31}$.

Z kolei, w 1884 r. powstał pierwszy akt prawny dotyczący Alaski (Organic Act). Regulował on funkcjonowanie władz federalnych, a także dostarczył prawnych podstaw dla tworzenia systemu szkolnictwa. Pod koniec XIX w. federalny rząd utworzył dzienne szkoły w większości osad, a także rozpoczął proces powstawania szkół zawodowych z internatami. W tym czasie $99 \%$ uczniów stanowili tubylcy ${ }^{32}$.

27 Ibidem, s. 33.

${ }^{28}$ Report of the Education task Force, s. 8.

29 S. Z. Klausner, E. F. Foulks, Eskimo Capitalists. Oil, Politics and Alcohol, New Jersey 1982, s. 36.

${ }^{30}$ N. A. Chance, The Iñupiat and Arctic Alaska. An Ethnography of Development, Montreal 1990, s. 47.

${ }^{31}$ C. Barnhard, op. cit., s. 5-6.

${ }^{32}$ Report of the Education task Force, s. 8. 
Warto w tym miejscu zwrócić uwagę na politykę tworzenia dualnego systemu szkół na Alasce. Tworzenie oddzielnego systemu (segregowanego rasowo) dla dzieci białych oraz dzieci pochodzących z tubylczych grup etnicznych miało kilka przyczyn. Jedną z nich było powiększanie się nie-tubylczej, białej populacji w większych miejscowościach Alaski. Jej reprezentanci pragnęli utworzenia osobnych szkół dla własnych dzieci. Inną przyczyną była niechęć władz terytorium do finansowania edukacji tubylców (która to konieczność została narzucona władzom lokalnym przez władze państwowe - federalne). Wynikała ona m.in. z uchwalonej w 1905 r. przez Kongres Ustawy Nelsona [Nelson Act], która zakładała tworzenie szkół we wszystkich osadach Alaski. W 1912 r. Kongres uchwalił drugi organiczny akt prawny (Second Organic Act). Jednym z jego elementów stało się stworzenie podwalin dla terytorialnego zarządzania szkołami. I choć na podstawie nowego aktu prawnego Władze Terytorialne (Territorial Legislature) nie posiadały możliwości zmiany postanowień istniejącego amerykańskiego prawa oświatowego, to jednak w 1915 r. podjęły one próbę utworzenia własnego jednorodnego systemu szkolnego. Był to jednak system nieobejmujący szkół przeznaczonych dla reprezentantów mniejszości, lokalne władze bowiem były niechętne wobec utrzymywania szkół dla tubylców. W efekcie prawnych postanowień, w 1917 r. usankcjonowano status prawny szkół na Alasce wyłączający szkoły tubylcze spod jurysdykcji władz terytorialnych i tworzący w istocie rasowo segregowany system szkolny ${ }^{33}$.

W konsekwencji powstał dualny system szkolnictwa zarządzany przez dwie instytucje. $Z$ jednej strony funkcjonował system dla białych dzieci i pewnej (niewielkiej) części dzieci ze związków mieszanych - zarządzany przez władze terytorium. Z drugiej strony, powstał system szkół zarządzanych przez federalne Biuro Edukacji [Bureau of Education]. Celem federalnego Biura Edukacji stała się jak najszybsza asymilacja tubylczych populacji w główny nurt amerykańskiego systemu wartości. Warto zauważyć, że proces asymilacji poprzez edukację prowadzony był bez żadnego rozpoznania różnic pomiędzy odmiennymi grupami zamieszkującymi Alaskę, a także ich kulturą i językiem ${ }^{34}$. Takie cele działania systemu szkolnictwa na Alasce były zgodne z polityką władz edukacyjnych na szczeblu narodowym. W. Churchill stwierdza w tym kontekście, że bez względu na to czy podmiotem prowadzacym szkoły z internatami było państwo czy kościót, w każdym momencie ich powstania $i$ w kazdym miejscu ich rezultaty byty takie same. Ich zadaniem była „dekulturacja” i ,wynarodowienie” dzieci pochodzących z tubylczych społeczności, i wprowadzenie ich w kulturę zachodnią - uczynienie z nich małych białych $l u d z i^{35}$. Działania takie podejmowane były we wszystkich obszarach USA wobec amerykańskich Indian, zgodnie z zasadą zabić Indianina, ocalić człowieka (czy w innym sformułowaniu usunąć Indianina lecz stworzyć człowieka). Zgodnie z tym założeniem, jed-

\footnotetext{
33 Ibidem, s. 10.

${ }^{34}$ C. Barnhard, op. cit., s. 6-7.

${ }^{35}$ W. Churchill, Kill the Indian, Save the Man. The Genocidal Impact of American Indian Residential Schools, San Francisco 2004, s. 28.
} 
nostka będąca Indianinem nie może być człowiekiem. Jeśli zatem ma być człowiekiem, to nie może pozostać Indianinem ${ }^{36}$.

W 1917 r. utworzono zatem 46 terytorialnych szkół w obszarach wiejskich kształcących 1162 uczniów. Równocześnie powstało 71 wiejskich szkół federalnych kształcących 3500 uczniów. W rzeczywistości jednak, system segregacji na Alasce nie rozwijał się w kierunkach, jakie planowano przy jego tworzeniu. Kwestie finansowe legły u podstaw zaniechania praktyki dublowania szkół w małych wiejskich społecznościach. W wielu z nich podejmowały kształcenie zarówno dzieci białe, jak i te pochodzące z mniejszości tubylczych. Trzeba zaznaczyć, że w programach kształcenia w szkołach federalnych (w przeciwieństwie do obowiązujących w instytucjach prowadzonych przez władze terytorium), pojawiały się wybrane tubylcze treści (jak np. tańce czy gry) ${ }^{37}$.

Warto zauważyć, że rozwój polityki edukacyjnej Stanów Zjednoczonych wobec mniejszości etnicznych na Alasce, w pewnych aspektach różnił się od tej, która obejmowała pozostałe 48 stanów. Z drugiej strony, od czasu gdy Stany Zjednoczone odkupiły Alaskę od Rosji w 1867 r., działania polityczne, programy i relacje, jakie rozwijane były pomiędzy rządem a amerykańskimi Indianami zaczęły mieć znaczący wpływ również na tubylczą populację Alaski. Trzeba stwierdzić, że znacząca część rozwiązań dotyczących polityki edukacyjnej nie była tworzona dla tubylczych mieszkańców Alaski, ani także w kontekście warunków panujących w tym stanie. W większości to polityka wobec Indian miała istotny wpływ na funkcjonowanie szkolnictwa na Alasce. Ponadto, jak zauważa C. Barhardt, polityka powstała $w$ tym najwcześniejszym okresie dała podwaliny dla państwowej praktyki szkolnej dla tubylczych populacji Alaski, które obecne sq nawet współcześnie ${ }^{38}$.

Od 1931 r. działania podejmowane przez federalne Biuro Edukacji dotyczyły nie tylko utrzymywania systemu szkolnego w najmniej zurbanizowanych obszarach Alaski, lecz także rozwijania opieki medycznej, organizacji hodowli reniferów (której celem było przekształcenie dotychczasowych sposobów gospodarowania grup tubylczych), tworzenie sieci handlowych, funkcjonowania floty przybrzeżnej (North Star), której celem stało się zaopatrywanie najbardziej odizolowanych osad na wybrzeżu, a także opieka nad sierotami. Biuro edukacji tworzyło również nowe instytucje edukacyjne (m.in. kilka szkół zawodowych) ${ }^{39}$.

Uchwalenie w 1934 r. indiańskiej ustawy Indian Reorganization Act (IRA), stało się punktem zmieniającym założenia amerykańskiej polityki edukacyjnej wobec mniejszości. Nowe prawo umożliwiało tworzenie tubylczych, plemiennych instytucji, a także prowadzenia działalności gospodarczej przez reprezentantów grup etnicznych. Celem zmian było zwiększenie ich samowystarczalności ${ }^{40}$.

\footnotetext{
${ }^{36}$ Ibidem, s. 13-14.

${ }^{37}$ Report of the Education task Force, s. 10-11.

${ }^{38}$ C. Barnhard, op. cit., s. 3.

39 Report of the Education task Force, s. 11.

${ }^{40}$ N. A. Chance, op. cit., s. 53.
} 
W latach 30., działania kongresu zmierzały zatem do stworzenia polityki oświatowej służącej z jednej strony integracji tubylczych grup etnicznych w kulturę zachodnią, a z drugiej zachowaniu kultury tubylczej. Takie postępowe poglądy (związane z myśleniem o społecznościach etnicznych jako całościach kulturowych oraz koniecznością ich integracji oraz rozwijania przez nie samorządności), reprezentowane były m.in. przez Komisarza Biura ds. Indian Johna Colliera. W rzeczywistości jednak, założenia proponowanej polityki miały nieduże szanse powodzenia. Wielcy posiadacze ziemscy wraz z konserwatywnym Kongresem storpedowali większość pomysłów i proponowanych rozwiązań prawnych ${ }^{41}$. Niewystarczające finansowanie szkół terytorialnych z funduszy federalnych (szkół, w których kształciła się znaczna część dzieci ze społeczności tubylczych), spowodowało wyraźną niechęć władz terytorialnych Alaski wobec ich prowadzenia i utrzymywania. W 1939 r. prowadzenia 18 takich szkół przekazano władzom Biura ds. Indian [Bureau of Indian Affairs $]^{42}$.

\section{Powojenna polityka edukacyjna na Alasce}

Początek lat 40. (i związane z tym działania wojenne) spowodowały intensyfikację kontaktów pomiędzy ludnością tubylczą a pozostałymi reprezentantami społeczeństwa amerykańskiego. W tym czasie, rozpoczęto realizację nowej polityki asymilacji. Zakładała ona podejmowanie zintensyfikowanych działań asymilacyjnych wobec wybranych jednostek pochodzących ze społeczności tubylczych (zamiast oddziaływania na całe grupy). Równocześnie, podejmowano działania w zakresie edukacji dzieci z grup tubylczych, bądź to w szkolnictwie dla białych lub w odrębnych instytucjach (zgodnie z zasadą „oddzielnie lecz równo" [separate but equal]). Po zakończeniu wojny, władze terytorialne zaproponowały utworzenie jednorodnego systemu szkolnictwa, z wspólnym programem kształcenia dla wszystkich uczniów. Federalne Biuro ds. Indian zmierzało jednak do kontynuacji funkcjonowania odrębnego systemu szkolnego dla tubylczej ludności Alaski ${ }^{43}$.

Nadal kontynuowano (rozpoczętą na początku lat 40.) politykę indywidualnej asymilacji. W tym celu, w 1947 r. utworzono dużą szkołę średnią na terenie morskiej bazy powietrznej w miejscowości Sitka. Oferowała ona zarówno kształcenie ogólne, jak i różne formy edukacji zawodowej. Szkoła Mount Edgecumbe przeznaczona była dla młodzieży pochodzącej z tubylczych grup etnicznych, zamieszkujących na całym terytorium Alaski. Podejmowano też działania na rzecz tworzenia kolejnych szkół z internatami w innych stanach. W wielu przypadkach, gdy nie wystarczało miejsc w szkole Mount

${ }^{41}$ R. Makka, A. Fleras, The Politics of Indigenity. Challenging the State in Canada and Aotearoa New Zealand, Melbourne 2005, s. 203.

42 Report of the Education task Force, s. 11.

43 Ibidem, s. 12. 
Edgecumbe, wysyłano młodych ludzi do szkół z internatami funkcjonujących w innych $\operatorname{stanach}^{44}$.

Tabela. Chronologiczne ujęcie głównych zmian prawnych w systemie edukacji na Alasce w latach 1867-1976

\begin{tabular}{|c|c|}
\hline Rok & Przekształcenia w systemie edukacji i akty prawne \\
\hline 1867 & Stany Zjednoczone odkupiły Alaskę od Rosji \\
\hline 1884 & $\begin{array}{l}\text { Organic Act: Kongres USA przeniósł odpowiedzialność za dostarczanie edukacji dla dzieci wszystkich } \\
\text { ras na terytorium kraju, na Biuro Edukacji (Bureau of Education) w Ministerstwie Spraw Wewnętrz- } \\
\text { nych (Department of the Interior) }\end{array}$ \\
\hline 1900 & $\begin{array}{l}\text { Kongres USA przyznał gminom na Alasce władzę prawną w zakresie tworzenia i rejestrowania szkół } \\
\text { oraz utrzymywania ich z podatków }\end{array}$ \\
\hline 1905 & $\begin{array}{l}\text { Nelson Act: Kongres USA umożliwił tworzenie szkół poza zrzeszonymi miastami, a gubernator tery- } \\
\text { torium stał się oficjalnym zarządcą publicznego szkolnictwa }\end{array}$ \\
\hline 1917 & $\begin{array}{l}\text { Uniform School Act: Kongres USA powołał Terytorialną Radę Edukacji (Territorial Board of Educa- } \\
\text { tion) oraz utworzył stanowisko Komisarza ds. Edukacji (Commissioner of Education) }\end{array}$ \\
\hline 1931 & $\begin{array}{l}\text { Kongres USA przeniósł odpowiedzialność za szkolnictwo tubylcze na Alasce z Biura Edukacji na } \\
\text { Urząd ds. Indian (Office of Indian Affairs) (oba w ramach Ministerstwa Spraw Wewnętrznych) }\end{array}$ \\
\hline 1934 & $\begin{array}{l}\text { Johnson-O'Malley Act: Kongres USA przyznał wsparcie finansowe stanom w celu tworzenia progra- } \\
\text { mów kształcenia dla tubylców w szkołach publicznych, a także stworzył podstawy prawne dla funk- } \\
\text { cjonowania służb w sferze ochrony zdrowia, szkolnictwa i spraw społecznych }\end{array}$ \\
\hline 1951 & Johnson-O 'Malley Act - rozwinięcie ustawy: Kongres USA rozszerzył rozporządzenia ustawy na Alaskę \\
\hline 1951 & $\begin{array}{l}\text { PL 815-874: Kongres USA przyznał fundusze federalne na funkcjonowanie szkół w bazach wojsko- } \\
\text { wych }\end{array}$ \\
\hline 1959 & Kongres USA uchwalił Ustawę Stanową Alaski (Alaska Statehood Act) \\
\hline 1963 & $\begin{array}{l}\text { Borough Act: Ciało Ustawodawcze Stanu Alaska (Alaska State Legislature) stworzyło dziewięć okrę- } \\
\text { gów (borough), w ramach których funkcjonować miały wszystkie instytucje edukacyjne lokalnych } \\
\text { dystryktów szkolnych }\end{array}$ \\
\hline 1965 & $\begin{array}{l}\text { Division of State-Operated School System (SOS): Wydział Edukacji Stanu Alaska (Alaska State De- } \\
\text { partment of Education) dokonał reorganizacji i stworzył nowy podział (division), który przeniósł od- } \\
\text { powiedzialność na szkoły funkcjonujące w obszarach wiejskich oraz szkoły funkcjonujące w bazach } \\
\text { wojskowych }\end{array}$ \\
\hline 1971 & $\begin{array}{l}\text { Alaska State-Operated School System: Ciało Ustawodawcze Stanu Alaska stworzyło nowy system } \\
\text { jako niezależną agencję i przeniosło odpowiedzialność za działanie oświaty z Wydziału Edukacji na } \\
\text { szkoły wiejskie i szkoły funkcjonujące w bazach }\end{array}$ \\
\hline 1975 & $\begin{array}{l}\text { Alaska Unorganized Borough School District: Ciało Ustawodawcze Stanu Alaska zlikwidowało Ala- } \\
\text { ska State-Operated School System, i stworzyło Okręgowy System Niezrzeszonych Dystryktów Szkol- } \\
\text { nych (Unorganized Borough School District) }\end{array}$ \\
\hline 1976 & $\begin{array}{l}\text { Regional Educational Attendance Areas (REAAs): Ciało Ustawodawcze Stanu Alaska zlikwidowało } \\
\text { Okręgowy System Niezrzeszonych Dystryktów Szkolnych i stworzyło } 21 \text { Regionalnych Obszarów } \\
\text { Szkolnych (Regional Educational Attendance Areas). Szkoły funkcjonujące w bazach zawarły umowę } \\
\text { z najbliższym dystryktem okręgowym lub weszły w skład REAAs }\end{array}$ \\
\hline
\end{tabular}

Źródło: J. Orvik, Cross-cultural education in Alaska, w: Education of Minorities, red. J. Megarry, S. Nisbet, E. Hyde, New York 1981, s. 285.

44 Ibidem. 
W latach 40. większość dzieci z grup tubylczych podejmowała kształcenie w szkołach podstawowych i na tym etapie kończyła swoją edukację. Ponadto, jeszcze na początku lat 50. pewne grupy dzieci ze społeczności tubylczych nie były wcale objęte edukacją szkolną. W kolejnych latach, dzieci z obszarów, w których nie funkcjonowały szkoły umieszczano w szkołach podstawowych z internatami. Polityka Biura ds. Edukacji Indian zmierzała nie tylko do odcięcia dzieci i młodzieży od środowiska lokalnego, lecz również w wielu przypadkach zniechęcała je do powrotu ${ }^{45}$.

Od 1951 r., Biuro ds. Edukacji Indian rozpoczęło proces przenoszenia kompetencji zarządzania niektórymi szkołami na władze terytorialne Alaski. Proces ten był systematycznie kontynuowany po uzyskaniu przez Alaskę statusu stanu w 1959 r., a faktycznie zakończył się dopiero w 1985 r. Wraz z wejściem Alaski do Unii, podjęto zmiany w sferze szkolnictwa. W latach 1965-1966 utworzono Stanowy System Szkolny [State Operated School System], którego celem stało się centralne zarządzanie wiejskimi szkołami na Alasce ${ }^{46}$.

W rzeczywistości, dopiero w połowie lat 60. dokonywano w Stanach Zjednoczonych krytycznych analiz sytuacji ludów tubylczych. Wiele $\mathrm{z}$ nich opublikowano jako raporty rządowe. Jednym z kluczowych zagadnień poruszanych w raportach był stan tubylczego szkolnictwa, a także poziom wykształcenia populacji. Konsekwencją tych raportów stały się (podejmowane w kolejnych dekadach) próby transformacji tubylczego szkolnictwa. Trzeba przy tym zauważyć, że w USA, podobnie jak w Kanadzie (a także w Skandynawii), realne przekształcenia w edukacji dla tubylczych grup etnicznych nastąpiły dopiero w latach 70 .

Warto w tym miejscu wskazać przynajmniej dwa raporty. Pierwszy z nich, opracowywany został w latach 1968-1969 przez specjalną senacką podkomisję śledczą pod przewodnictwem senatora Roberta Kennedy’ego (i stąd często nazywany jest „Raportem Kennedy'ego"). Stanowi on krytyczną analizę czterech dekad funkcjonowania systemu szkolnictwa przeznaczonego dla reprezentantów tubylczych grup etnicznych, wraz z ich praktykami przymusowej asymilacji i dyskryminacji. Sam tytuł raportu opublikowanego w 1969 r. jest bardzo wymowny i wiele mówi o jego zawartości: „Edukacja Indian: Narodowa Tragedia - Narodowe Wyzwanie" [Indian Education: A National Tragedy A National Challenge]. Drugi z kolei raport, opracowany został w latach 1967-1971, na zamówienie Ministerstwa Edukacji Stanów Zjednoczonych. Wspomniany raport, pod tytułem „Narodowe Studium Edukacji Amerykańskich Indian” [National Study of American Indian Education] powstał przy współpracy 8 ośrodków uniwersyteckich, które podjęły badania w 26 społecznościach (a w badaniach wzięło udział 40 szkół z różnych stanów, m.in. z Alaski). Również i ten raport, stanowił krytyczną recenzję polityki oświatowej władz Stanów Zjednoczonych wobec zamieszkujących to terytorium tubylczych społeczności ${ }^{47}$.

\footnotetext{
${ }^{45}$ C. Barnhard, op. cit., s. 3.

${ }^{46}$ Report of the Education task Force, s. 12.

${ }^{47}$ C. Barnhard, op. cit., s. 14-15.
} 
Konsekwencją wspomnianych raportów stały się przekształcenia w sferze edukacji tubylczej. W 1972 r. uchwalono nową ustawę [Indian Education Act], której założenia skierowane były na dostosowanie szkolnictwa publicznego do potrzeb autochtonicznych społeczności. Ponadto, rozpoczęto różnorodne działania służące rozwojowi inicjatyw tubylczych (takie jak granty celowe, programy federalne służące finansowaniu instytucji oraz organizacji plemiennych), a także powstawaniu państwowych instytucji służących edukacji indiańskich dzieci oraz dorosłych. W kolejnych latach powstawały także ustawy służące tworzeniu tubylczych instytucji kształcenia, bądź przejmowaniu zarządzania poszczególnymi szkołami (Indian Self-Determination, Education Assistance Act). Jakkolwiek, wraz z uchwalaniem tych ustaw oraz następującą po nich praktyką pojawiło się wiele głosów krytycznych, sugerujących, że stanowią one jedynie tubylczą ,iluzję kontroli” nad edukacją, warto jednak zauważyć, że w kolejnych latach systematycznie wzrastała liczba reprezentantów tubylczych grup etnicznych we władzach oświatowych Biura ds. Indian ${ }^{48}$.

Szczególny wpływ na przemiany w zakresie edukacji tubylczej na Alasce miały rozwiązania prawne, administracyjne i gospodarcze powiązane z uchwaleniem Ustawy o roszczeniach ludów tubylczych ws. gruntów (Alaska Native Claims Settlement Act ANCSA). W wyniku ustaleń odszkodowawczych, tubylcze społeczności na Alasce otrzymały prawie 44 mln akrów ziemi oraz 962,5 mln dolarów amerykańskich. Zostały one przekazane 12 tubylczym korporacjom, które zostały utworzone w ramach odmiennych regionów kulturowych i językowych stanu. W konsekwencji, regionalne korporacje stały się największymi właścicielami ziemskimi na Alasce. Wiele tubylczych społeczności uzyskało w ten sposób dostęp do znacznych zasobów finansowych i władzy. Regionalne korporacje uzyskały równocześnie prawa do eksploatacji zasobów naturalnych, co w związku z odkryciem i rozpoczęciem wydobycia ropy naftowej, wiązało się z udziałem w zyskach pochodzących ze sprzedaży tego surowca ${ }^{49}$.

Regionalne korporacje uzyskały prawo do rozwijania i finansowania wielu instytucji, jak choćby służby zdrowia, czy szkolnictwa. Ustawa ta zmieniła również sposoby własnego postrzegania wielu reprezentantów społeczności tubylczych. Przestali być już oni obywatelami „drugiej kategorii”, stali się bowiem pełnoprawnymi właścicielami prawie $12 \%$ terytorium Alaski. $Z$ drugiej strony, ustawa ta pozbawiła tubylczych mieszkańców stanu praw do roszczeń w sprawie pozostałej części (ponad 88\%) stanu Alaska. Ponadto, w kolejnych latach rynkowa działalność tubylczych korporacji działających „dla zysku” stała się podstawą krytyki ${ }^{50}$. Cztery dekady funkcjonowania ustawy wskazują, że nie wszystkie społeczności potrafiły wykorzystać szanse i rozwiązania, jakie stworzył im ten akt prawny. Część z nich gospodaruje odpowiedzialnie własnymi zasobami. Inwestują one zyski, tworzą fundacje dla przyszłych tubylczych pokoleń, a także rozwijają programy ochrony i rewitalizacji kultury tubylczej. Jednak niektóre z organizacji systematycz-

\footnotetext{
${ }^{48}$ Ibidem, s. 16-17.

49 G. Osherenko, O. R. Young, The Age of the Arctic: hot conflicts and cold realities, Cambridge 1989, s. 78 .

50 Ibidem, s. 79.
} 
nie sprzedają ziemię (głównie koncernom naftowym), a uzyskane fundusze rozdzielają pomiędzy swoich członków. Wydawanie środków finansowych na doraźne potrzeby (lub wręcz rozdawnictwo pieniędzy) sprawiają, że idea zachowania własności dla przyszłych pokoleń pozostaje $\mathrm{w}$ znacznej mierze zapomniana i zaprzepaszczana ${ }^{51}$.

Jak już o tym pisano, pod koniec lat 60 . i na początku kolejnej dekady narastała krytyka szkolnictwa tubylczego, oferowanego przez władze federalne na Alasce. Krytyka ta zawarta była we wspomnianych wcześniej, kolejnych raportach, jakie powstawały na zlecenie rządu Stanów Zjednoczonych. Równocześnie, wielu autorów zajmujących się problematyką edukacji autochtonicznych grup etnicznych wskazywało, że państwo postrzega tubylcze szkolnictwo na Alasce w kategoriach „,problemu”. W szczególności, zwracano uwagę na niskie osiągnięcia tubylczych uczniów, a także niewielkie możliwości w zakresie kontynuacji przez nich kształcenia na poziomie średnim ${ }^{52}$.

W konsekwencji, federalne władze oświatowe zdecydowały się na likwidację niewydolnego systemu (State Operated School System) i zastąpienie go bardziej zdecentralizowanym układem dystryktów szkolnych. W 1975 r. utworzono 21 zarządzanych regionalnie dystryktów szkolnych, których celem było zwiększenie lokalnej kontroli nad edukacją. Gminne Komitety Szkolne (Community School Committees) zastąpiły regionalne rady szkolne. Ich celem stało się rozszerzenie wpływu społeczności lokalnych na zarządzanie szkołami. Oznaczało to zmianę polityki federalnej wobec społeczności tubylczych. Od tego czasu zakładano zwiększenie wpływu organizacji tubylczych na szkolnictwo, jak również wybór członków komitetów szkolnych ${ }^{53}$.

Pod koniec lat 70. podjęto również działania w zakresie rozwoju sieci szkół średnich. Rozwój tego sektora szkolnictwa w latach 60. zahamowany został na początku lat 70 . Przyczyną stagnacji były z jednej strony ogromne trudności tubylczej młodzieży powracającej ze szkół internatowych do rodzinnych osad - w zakresie znajdowania pracy i odnalezienia „sposobu na życie”. Z drugiej strony, pojawiło się wiele problemów mentalnych i psychicznych, powiązanych z szerzącymi się zjawiskami alkoholizmu, a także dramatycznie wzrastającym poziomem samobójstw wśród młodych ludzi. Wszystko to wpłynęło na odwrót od koncepcji rozwoju regionalnego systemu szkolnictwa średniego. Zmiany pod koniec lat 70. spowodowały powrót do tej koncepcji. W konsekwencji dążenia do zapewnienia wszystkim uczniom konstytucyjnego prawa do uzyskania 12 lat edukacji (K-12), w większości miejscowości, w których funkcjonowała szkoła podstawowa, utworzono szkoły średnie ${ }^{54}$.

Choć rozwój szkolnictwa w kolejnych dekadach sprzyjał wyrównywaniu szans edukacyjnych dzieci i młodzieży pochodzących z mniejszości tubylczych, to jednak równo-

${ }^{51}$ G. L. Pullar, Indigenous Self-Government and Political Institutions in Alaska, w: An Indigenous Parliament? Realities and Perspectives in Russia and the Circumpolar North, IWGIA Document No. 116, Copenhagen 2005, s. 113-114.

${ }_{52}$ M. Szasz, Education and the American Indian: the Road to Self-determination Since 1928, Albuquerque 1974, s. 127-128.

${ }_{53}$ Report of the Education task Force, s. 12-13.

${ }^{54}$ Ibidem, s. 13. 
cześnie istniało (i do dziś funkcjonuje) wiele przeszkód w uzyskiwaniu podobnych rezultatów. Można wskazać na wiele przyczyn porażek edukacyjnych uczniów, które powiązane są ze specyfiką problemów tubylczego szkolnictwa na Alasce. Trzeba do nich zaliczyć przede wszystkim niewielką liczbę nauczycieli rozumiejących specyfikę pracy z tubylczymi uczniami (w tym nauczycieli tubylczych), wysoki wskaźnik rotacji nauczycieli, obce kulturowo środowisko szkolne, brak związku programów kształcenia z realiami życia w obszarach arktycznych, rozdźwięk między celami kształcenia w szkolnictwie „zachodnim” a tymi, które wynikają z potrzeb lokalnych społeczności, niski poziom aspiracji edukacyjnych uczniów, ogólny niski poziom wyposażenia małych wiejskich szkół (w których kształci się znaczna część tubylczej populacji Alaski), a także czynniki społeczne (w tym biedę i uzależnienia) ${ }^{55}$.

Współcześnie można wyróżnić trzy typy szkół na Alasce. Pierwszy z nich to szkoły funkcjonujące w obszarach wiejskich. Uczęszczają do nich przede wszystkim uczniowie z tubylczych społeczności Alaski. Większość spośród szkół tego typu funkcjonuje w oparciu o dwunastoklasowy system kształcenia (K-12). Z powodu niewielkiej liczby uczniów, kształcenie zorganizowane jest jednak w sposób pozwalający nauczycielowi na pracę z uczniami w różnym wieku w tej samej grupie (kilka klas w jednej). Z tego samego powodu, szkoły takie zatrudniają niewielu nauczycieli (ich liczba może wahać się od 1 do $10 \mathrm{w}$ każdej szkole). Zwykle, w pierwszych latach kształcenie zorganizowane jest w oparciu o język tubylczy (np. język alutiiq, cupik, gwichin, inupiat, syberyjski jupik, tlingit, czy środkowy jupik). W niektórych przypadkach zdarza się, że poszczególne szkoły stosują programy kształcenia zorientowane w znacznym stopniu na treści tubylcze (włączając język, cele kształcenia i tradycyjną wiedzę). W pewnych dystryktach, takie treści mogą być ponadto zawarte w ogólnie obowiązujących programach kształcenia. Ważnym aspektem funkcjonowania wiejskich szkół jest włączanie członków lokalnych społeczności w proces kształcenia; działają oni również jako wsparcie dla nauczycieli języka. Większość nauczycieli pochodzących ze społeczności tubylczych zatrudnionych jest w tego typu szkołach. Trzeba stwierdzić, że odsetek uczniów kończących szkoły średnie w obszarach wiejskich, jest znacznie niższy niż w miastach.

Drugim typem są szkoły w wiejskich centrach regionalnych i/lub znajdujących się w systemie dróg lub szlaków wodnych (Rural Regional Center and Road System/Marine Highway Schools). Szkoły te funkcjonują - podobnie jak szkoły pierwszego typu - na poziomie podstawowym i średnim. Są to znacznie większe instytucje, działające z jednej strony w centrach regionalnych (takich jak Barrow, Bethel, Kotzebue czy Nome). W miejscowościach tych zamieszkuje przede wszystkim populacja tubylcza wraz z dużą grupą (około 30-50\%) populacji nie tubylczej. Szkoły tego typu działają także w miejscowościach znajdujących się na szlakach komunikacyjnych drogowych i wodnych dostępnych za pośrednictwem samochodu bądź promu (takich, jak: Kenai, Ketchikan, Sitka, czy Tok). Miejscowości te zamieszkiwane są głównie przez populacje nie-tubylcze. Szkoły drugiego typu łączą w sobie cechy szkół miejskich oraz wiejskich i zarządzane są - podobnie jak szkoły wiejskie - przez władze określonych dystryktów lub okręgów

\footnotetext{
55 Ibidem, s. 16-19.
} 
wchodzących w skład Regionalnych Obszarów Szkolnych (Regional Educational Attendance Areas - REAA). W szkołach tych funkcjonują programy kształcenia skierowane na jednostki z grup tubylczych, jednak ich zakres oraz zawartość zależy od liczby takich uczniów w konkretnych instytucjach.

Trzecim typem są szkoły funkcjonujące w miastach. Mowa tu przede wszystkim o trzech największych miastach Alaski (Anchorage, Fairbanks i Juneau). Szkoły tego typu funkcjonują podobnie jak instytucje w innych obszarach Stanów Zjednoczonych. Kształcą one bardzo zróżnicowaną pod względem etnicznym i językowym populację uczniów, przy czym uczniowie pochodzący z tubylczych społeczności Alaski stanowię największą mniejszość etniczną. Większość szkół tego typu posiada przynajmniej jeden program zorientowany na reprezentantów grup tubylczych (zarówno mniejszości eskimoskich, jak i amerykańskich Indian). Programy takie finansowane są z funduszy federalnych (np. na podstawie ustawy Johnson-O'Malley Act, czy Indian Education Act). W niektórych przypadkach wspierane są one z funduszy stanowych lub za pośrednictwem poszczególnych dystryktów. Programy zorientowane na tubylcze dziedzictwo kulturowe włączają specjalne wewnątrzszkolne przewodnictwo edukacyjne dla uczniów z mniejszości, obchodzenie tubylczych świąt i wydarzeń, czy zajęć powiązanych z tradycją i kulturą tubylczych społeczności ${ }^{56}$

Począwszy od lat 70. ubiegłego stulecia, podejmowano działania na rzecz rewitalizacji społeczności tubylczych, ich kultury i języka ${ }^{57}$. Większość takich działań podejmowanych była „oddolnie” - przez organizacje tubylcze powstające systematycznie na Alasce. Edukacja postrzegana była $\mathrm{z}$ tej perspektywy jako najbardziej skuteczny środek aktywizacji społeczności lokalnych, a także odrodzenia tubylczych wartości, języka i tradycji ${ }^{58}$.

W niektórych przypadkach, działania autochtonicznych organizacji zmierzały do stworzenia tubylczych programów edukacji, kompleksowo realizujących cele rewitalizacji kultury etnicznej. Przykładem może być (utworzony w miejscowości Bristol Bay) program X-CED (Cross-Cultural Education Development Program). Celem programu było stworzenie możliwości kształcenia tubylczych nauczycieli w ich własnym lokalnym środowisku ${ }^{59}$.

Procesy nauczania i uczenia się w tubylczych społecznościach Alaski miały zatem w założeniach programu X-CED - ulec zasadniczej transformacji. Ich głównym celem miało stać się oderwanie się od „zachodniego” stylu edukacji i zbliżenie do „tradycyjnego" stylu kształcenia i wychowania. Niezwykle ważnym elementem zmiany miała być także rewitalizacja kultury arktycznych społeczności ${ }^{60}$.

${ }^{56}$ C. Barnhard, op. cit., s. 22-23.

${ }^{57}$ E. Ahgeak MacLean, Culture and Change for Iñupiat and Yup'ik People of Alaska, w: Alaska Native Education..., s. 57.

58 J. Lipka, Transforming Schooling: From Possibilities to Actuality?, w: Transforming the Culture of Schools. Yup'ik Eskimo Examples, red. J. Lipka, G. V. Mohatt, London 1998, s. 190.

59 J. Orvik, Cross-cultural education in Alaska, w: Education of Minorities, red. J. Megarry, S. Nisbet, E. Hyde, New York 1981, s. 291.

${ }^{60}$ Ibidem. 


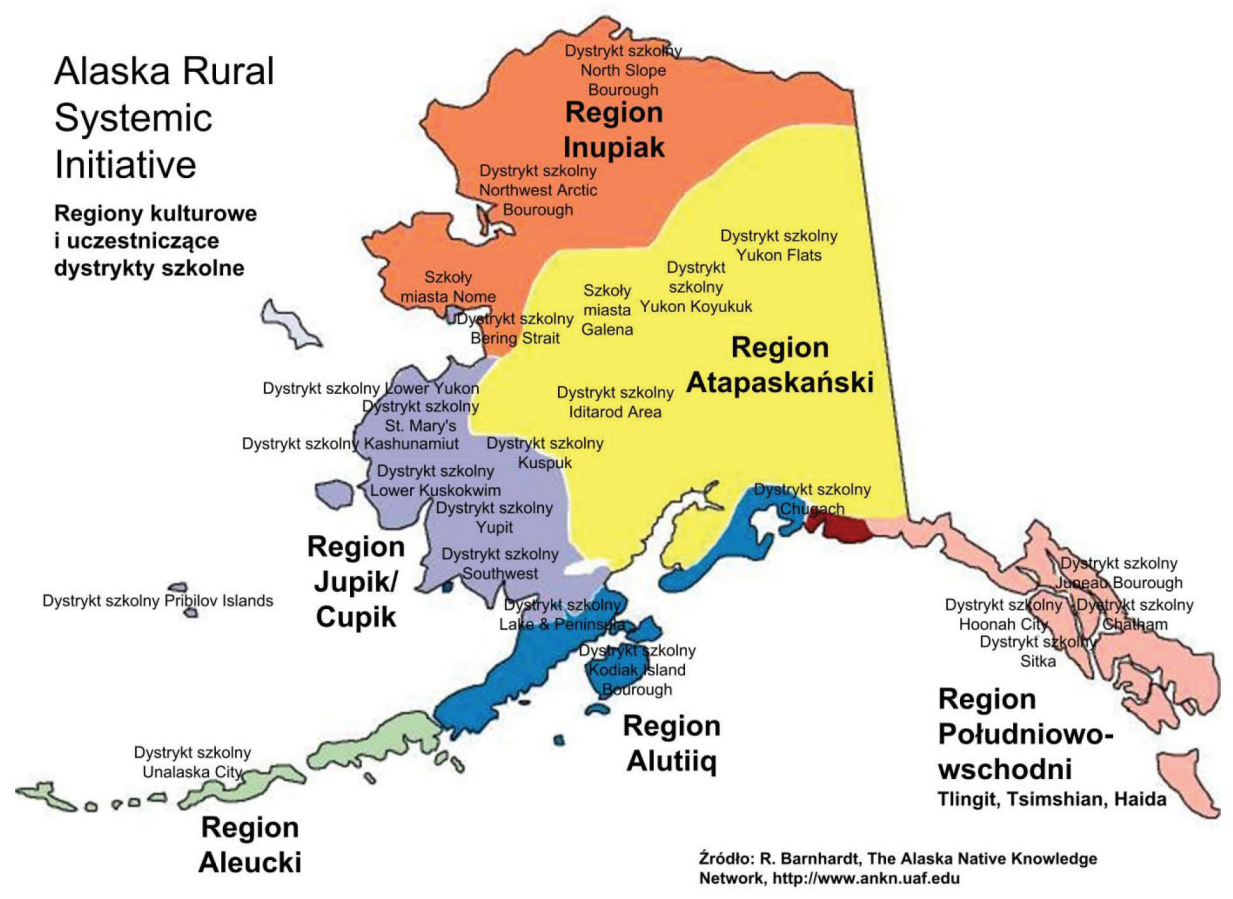

Mapa 2. Dystrykty szkolne i instytucje (w ramach regionów kulturowych), uczestniczące w Wiejskiej Sieci Inicjatyw Alaski (Alaska Rural Systemic Initiative - AKRSI)

Wiele celów zostało zrealizowanych już w kilka lat po rozpoczęciu programu (np. wykształcono kilkudziesięciu nauczycieli edukacji tubylczej). Także z perspektywy trzech dekad działania programu można stwierdzić, że stał się on kluczowy dla funkcjonowania edukacji tubylczej w wielu obszarach zamieszkiwanych przez społeczności na Alasce. Doskonale dostrzegalne było to w społecznościach Jupik, w których pojawiło się wielu nauczycieli tubylczych, którzy uzyskali wykształcenie w ramach działania programu. Niezwykle istotne dla rozwoju edukacji nauczycieli wywodzących się z autochtonicznych społeczności Jupik i zamieszkujących w tych obszarach było powstanie w 1986 r. organizacji Ciulistet. Ten związek tubylczych nauczycieli od momentu powstania podejmował zintegrowane działania na rzecz zachowania i rewitalizacji tubylczej kultury i języka jupik. Równocześnie, celem działania stało się wspieranie tubylczych nauczycieli w ich pracy (zarówno w sferze tworzenia materiałów dydaktycznych, opracowywania programów kształcenia, jak i rozwijania relacji pomiędzy szkołami a środowiskiem lokalnym $)^{61}$.

${ }^{61}$ J. Lipka, op. cit., s. 189-191. 
Także kolejne dekady, aż po czasy współczesne są czasem rozwijania istniejących i wprowadzania nowych rozwiązań w sferze edukacji tubylczej. Na przykład w latach 90., poza działaniami na rzecz rewitalizacji zagrożonych języków, rozwijania tradycyjnych form i programów kształcenia, podejmowano także szerokie inicjatywy w zakresie dokumentacji, opracowywania oraz integracji wiedzy tubylczej. Jedną z najważniejszych inicjatyw rozpoczętych na początku lat 90 . stała się strategia reformy edukacji tubylczej, nazwana Wiejską Siecią Inicjatyw Alaski (Alaska Rural Systemic Initiative - AKRSI). Działania na rzecz utworzenia organizacji zrealizowane zostały w 1994 r. Skupia ona ponad 50 organizacji działających na rzecz edukacji w wiejskich obszarach Alaski. Instytucjonalnym wsparciem dla tej inicjatywy stała się Federacja Tubylcza Alaski [Alaska Federation of Natives] oraz Uniwersytet Alaski (University of Alaska Fairbanks), wraz z funduszami organizacji państwowych i samorządowych ${ }^{62}$.

Działania podejmowane lokalnie przez poszczególne szkoły oraz organizacje tubylcze były koordynowane na poziomie organizacji AKRSI. Równocześnie, w każdym roku podejmowano działania tematyczne, których celem stało się podejmowanie zintegrowanych działań we wszystkich współpracujących instytucjach i obszarach Alaski. Warto wskazać przykłady takich działań tematycznych: 1) dokumentacja wiedzy kulturowej/ naukowej, 2) praktyka tubylczego nauczania, 3) integracja kulturowego programu kształcenia ze standardami edukacyjnymi, 4) organizacji systemów wsparcia nauczycieli, 5) tworzenia właściwych kulturowo praktyk oceniania ${ }^{63}$.

Ponadto, rozpoczęto rozwijanie Sieci Wiedzy Tubylczej Alaski [Alaska Native Knowledge Network]. W jej ramach podejmowano wielotorowe działania służące stworzeniu zintegrowanego systemu wiedzy i organizacji, opartego na dokumentacji i materiałach edukacyjnych - służącego tubylczym populacjom Alaski.

Podsumowując, trzeba zauważyć niezwykle ważną rolę programu ochrony i rewitalizacji języków tubylczych na Alasce, prowadzoną w instytucjach kształcenia wyższego ${ }^{64}$. Funkcjonujące na Uniwersytecie Fairbanks Centrum Języków Tubylczych Alaski (Alaska Native Language Center) odgrywa kluczową rolę w zakresie dokumentacji i rewitalizacji ginących języków ${ }^{65}$.

${ }^{62}$ R. Barnhardt, A. O. Kawagley, Culture, Chaos and Complexity. Catalysts for Change in Indigenous Education, w: Alaska Native Education. Views From Within, red. R. Barnhardt, A. O. Kawagley, Fairbanks 2010, s. 200-201.

63 Ibidem, s. 208.

${ }^{64}$ M. L. Jennings, J. R. Collier, One University, Two Universes: Alaska Natives and the University of Alaska-Anchorage, w: Native American Studies in Higher Education. Models for Collaboration between Universities and Indigenous Nations, red. D. Champagne, J. Stauss, Walnut Creek 2002, s. 208-225.

${ }^{65}$ Por. Alaska Native Language Center Mission and Goal, adres Internetowy: Alaska Native Language Center, University of Alaska Fairbanks, adres Internetowy: http://www.uaf.edu/anlc/mission/ 


\section{Zakończenie}

Historia rozwoju i współczesne formy funkcjonowania szkolnictwa dla mniejszości tubylczych na Alasce ukazują tendencje obecne także w pozostałych obszarach Arktyki. Systematyczna działalność szkolnictwa, wraz z oddziaływaniem innych państwowych instytucji (wojska, urzędów), a także niejednokrotnie destrukcyjnym wpływem organizacji religijnych przyczyniły się do nieodwracalnych zmian w świadomości etnicznej tubylczych społeczności. Spowodowały one w konsekwencji trwałe zmiany tożsamości etnicznej ludów zamieszkujących od tysięcy lat obszary Arktyki. Początkowo, szkolnictwo wykorzystywane było przez Kościoły w procesie chrystianizacji. Następnie, wykorzystywano edukację do indoktrynacji ideologiami państwowymi (w szczególności narodowymi). I choć współcześnie różnorodne grupy etniczne i narodowe w obszarach Dalekiej Północy posiadają możliwości w sferze używania własnego języka i ochrony tożsamości, to jednak kryteria awansu społecznego za pośrednictwem systemu edukacji pozostały niezmienione. W konsekwencji, nawet reprezentanci dużych grup etnicznych są zdeterminowani - w swoich wyborach edukacyjnych i życiowych.

Współcześnie, dramat mniejszości tubylczych żyjących na Alasce oraz innych w obszarach podbiegunowych trwa, i nie należy oczekiwać, że zakończy się on w sposób „konstruktywny”. Dylemat „zachowania tożsamości” w warunkach wieloetnicznego społeczeństwa nic nie traci na swojej ostrości. Jednostki ze społeczności tubylczych zwykle muszą wybierać między osiągnięciem sukcesu edukacyjnego i społeczno-zawodowego (w ramach systemu wartości dominującej większości) a przywiązaniem do swojej tradycyjnej kultury.

\section{Bibliografia}

Ahgeak MacLean E., Culture and Change for Iñupiat and Yup'ik People of Alaska, w: Alaska Native Education. Views From Within, red. R. Barnhardt, A. O. Kawagley, Fairbanks 2010.

Alaska Native Language Center Mission and Goal, adres Internetowy: Alaska Native Language Center, University of Alaska Fairbanks, adres Internetowy: http://www.uaf.edu/anlc/mission/.

Barnhard C., A History of Schooling for Alaska Native People, „Journal of American Indian Education” 2001, t. 40, nr 1, s. 2.

Barnhardt R., Kawagley A. O., Culture, Chaos and Complexity. Catalysts for Change in Indigenous Education, w: Alaska Native Education. Views From Within, red. R. Barnhardt, A. O. Kawagley, Fairbanks 2010.

Burch E. S., Social Life in Northwest Alaska. The Structure of Iñupiaq Eskimo Nations, Fairbanks 2006.

Burch E. S., The Iñupiaq Eskimo Nations of Northwest Alaska, Fairbanks 1998.

Chance N.A., The Iñupiat and Arctic Alaska. An Ethnography of Development, Montreal 1990.

Churchill W., Kill the Indian, Save the Man. The Genocidal Impact of American Indian Residential Schools, San Francisco 2004.

Fienup-Riordan A., The Yupiit of Western Alaska, w: Endangered Peoples of the Arctic. Struggles to Survive and Thrive, red. M. M. R. Freeman, Westport 2000. 
Graburn N. H. H,. Strong B. S., Circumpolar Peoples: An Anthropological Perspective, "Pacific Palisades" 1973, s. 183.

Jahn A., Alaska, Warszawa 1966.

Jennings M. L., Collier J. R., One University, Two Universes: Alaska Natives and the University of Alaska-Anchorage, w: Native American Studies in Higher Education. Models for Collaboration between Universities and Indigenous Nations, red. D. Champagne, J. Stauss, Walnut Creek 2002.

Klausner S. Z., Foulks E. F., Eskimo Capitalists. Oil, Politics and Alcohol, New Jersey 1982.

Krauss M.E., Alaska Native Languages: Past, Present, Future, Fairbanks 1980.

Lipka J., Transforming Schooling: From Possibilities to Actuality?, w: Transforming the Culture of Schools. Yup'ik Eskimo Examples, red. J. Lipka, G. V. Mohatt, London 1998.

Makka R., Fleras A., The Politics of Indigenity. Challenging the State in Canada and Aotearoa New Zealand, Melbourne 2005.

Norris T., Vines P.L., Hoeffel E. M., The American Indian and Alaska Native Population: 2010, 2010 Census Briefs, United States Department of Commerce Economics and Statistics Administration, U.S. Census Bureau, adres Internetowy: http://www.census.gov/prod/cen2010/briefs/ c2010br-10.pdf.

Olchowik-Adamowska L., Biernacka E., Indianie Ameryki Pótnocnej, seria Mitologie Świata, Warszawa 2007.

Orvik J., Cross-cultural education in Alaska, w: Education of Minorities, red. J. Megarry, S. Nisbet, E. Hyde, New York 1981.

Osherenko G., Young O. R., The Age of the Arctic: hot conflicts and cold realities, Cambridge 1989.

Pullar G. L., Indigenous Self-Government and Political Institutions in Alaska, w: An Indigenous Parliament? Realities and Perspectives in Russia and the Circumpolar North, IWGIA Document No. 116, Copenhagen 2005.

Report of the Education task Force, Alaska Natives Commision/Alaska Federation of Natives, 1995, w: Alaska Native Education. Views From Within, red. R. Barnhardt, A. O. Kawagley, Fairbanks 2010.

Rowley S. D. M., Inua: Spirit World of the Bering Sea Eskimo, Washington 1988.

Szasz M., Education and the American Indian: the Road to Self-determination Since 1928, Albuquerque 1974.

Vakhtin N., The Russian Arctic between Missionaries and Soviets: The Return of Religion, Double Belief, or Double Identity?, w: Rebuilding Identities. Pathways to Reform in Post-Soviet Siberia, red. E. Kasten, Halle 2005.

Walendziak T., Eskimosi, seria Mitologie Świata, Warszawa 2008.

Williams M. S. T., The Comity Agreement: Missionization of Alaska Native People, w: The Alaska Native Reader. History, Culture. Politics, red. M. S. T. Williams, Durham 2009. 